\title{
Short Term Load Forecasting Using Artificial Neural Network \& Time Series Methods
}

\author{
Suman Adhikari, Prof. Dr. Laxman Poudel
}

\begin{abstract}
Short term Electric load forecasting is an important aspect of power system planning and operation for utility companies. Short term load forecasting (STLF) has always been one of the most critical, sensitive and accuracy demanding factors of the power systems. An accurate STLF improves not only the systems economic viability but also its safety, stability and reliability. The researcher presented in this works support Artificial Neural Network and Time Series Methods techniques in short term forecasting. This paper presents an investigation for the short term (one day to seven days, \& every months of one year) load forecasting the load demand of Nepal Electricity Authority (NEA) in Bishnumati Feeder of Balaju Substation, by using artificial neural network and time series methods.
\end{abstract}

Keywords - Short Term Load Forecasting (STLF), Neural Network, Backpropagation algorithm, Moving average

\section{INTRODUCTION}

Electric power is the one of the most major input factors in economic development. To support economic growth and meet power requirements continually in the future, load forecasting has become a very important task for electric utilities. Moreover, an accurate load forecast can helpful in developing a power supply strategy, financing, planning, market research and electricity management. However, up to now, the general style of load forecasting emphasized aggregate load forecasting. Such load forecasting results not only cannot identify where the power load takes place but also is not helpful for power facilities construction location planning. Besides, on the one hand, people want to enjoy the convenience of electricity in their daily life, but on the other hand, no one wants to have any power facilities constructed in their backyard. Regional load forecasting can determine the electricity power shortage area directly. On the basis of equity, power facilities may be constructed in the power shortage region.

Load forecasting, at several levels of power networks became a key instrument in modern power system operation. The reason for its growing importance is related, on the one hand to the emergence of the energy markets, demanding higher efficiency scores. Load forecasts can have significant implications on energy transactions, market shares and profits in competitive energy markets. Forecasting electricity prices and quantities in daily power markets are the most essential task and basis for any decision making.

The short term forecasts refers to hourly prediction of the load for a lead time ranging from one hour to several days out. The mid-term forecasts can either be hourly or peak load forecasts for a forecast horizon of one to several months ahead. Finally the long term forecasts refer to forecasts made for one to several years in the future.

A power system serves a major function of supplying its customers, (large and small) with economical and reliable electrical energy as much as possible. For adequate electricity to be supplied to the customers, their load demand must be known. The process of making these evaluations of future demand of load is called 'Load forecasting'. Load forecasting is the projection of electrical load that will be required by a certain geographical area considering previous electrical load usage in the said area Load forecasting helps to make vital decisions concerning the system, therefore, load forecasting is very crucial for successful effective and efficient operation of any energy system. If the system load forecast is overestimated, the system may overcommit the generation of power which will inadvertently lead to costly operation of the power system. On the other hand, if the system load forecast is underestimated, the reliability and security of the system may be compromised, resulting in power interruptions and customer dissatisfaction. The time period in which the forecast is carried out is fundamental to the results and use of the forecast. Shortterm forecast, which spans a period of one hour to one week, helps to provide a great saving potential for economic and secured operation of power system, medium-term forecast, which ranges from a week to a year, concerns with scheduling of fuel supply and maintenance operation and long-term forecast and is from a year upwards, is useful for planning operations.

The accuracy of forecast greatly depends upon the size of the power system network, reliability and outages. Forecasting becomes more complex with the smaller system. Hence, more accurate methods and additional information is required to get acceptable outputs. It becomes more complex with unpredictable occurrence of anomalous events. The quality and 
quantity of available load data, metrological data, sociological data etc. directly affect the quality of result. Identification of proper tool, management of information system has another important role in the model development. Good forecasting with limited information and with large number of constraints is major challenge faced by the all the power system engineers all around the world. The challenges is more pronounced by the fact that the information and constraints are completely different from one power system to other or one part of the world to other. No general algorithm or tool can be developed. Hence, for each system a specific method and algorithm has to be developed regarding information collection, data management, data filtration, model development and scope of implementation.

There are large varieties of mathematical methods that are used for load forecasting, the development and improvements of suitable mathematical tools will lead to the development of more accurate load forecasting techniques. The accuracy of load forecasting depends on the load forecasting techniques used as well as on the accuracy of forecasted weather parameters such as temperature, humidity etc. As per the recent trends artificial intelligence methods are the most pronounced for the STLF. From different artificial intelligence methods, fuzzy logic and artificial neural network are the most used. Among the two methods fuzzy logic for STLF is gaining.

\section{METHODOLOGY}

This study is focused on the short term load forecasting techniques using the different model of short term load forecasting. Similar day approach to the modern artificial intelligence has been studied and implemented all over the world in various power grid best suit. In Nepal, short term load forecasting is not implemented in real hour to hour or day to day forecasting because no accurate model and technique cannot be implemented in power sector of Nepal.

In this research different analytical technique are analyzed on the basis of Mean Absolute Percentage Error (MAPE) and Mean Absolute Deviation (MAD) between the actual and forecasted load. Both techniques use the feed forward back propagation neural network algorithm for both data training and data forecasting.

The basic Framework for this research methodology are listed is shown below

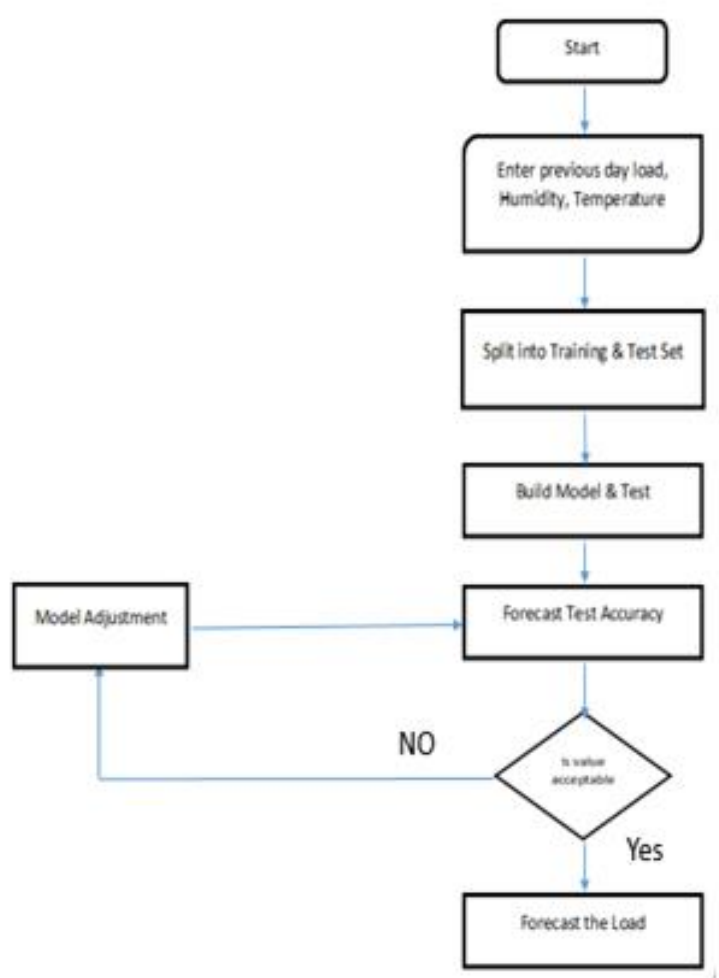

Figure 1: Forecasting Methodology by Artificial Neural Network (ANN)

The load forecasting methodology by moving averages and exponential smoothing technique can be shown in flow chart:

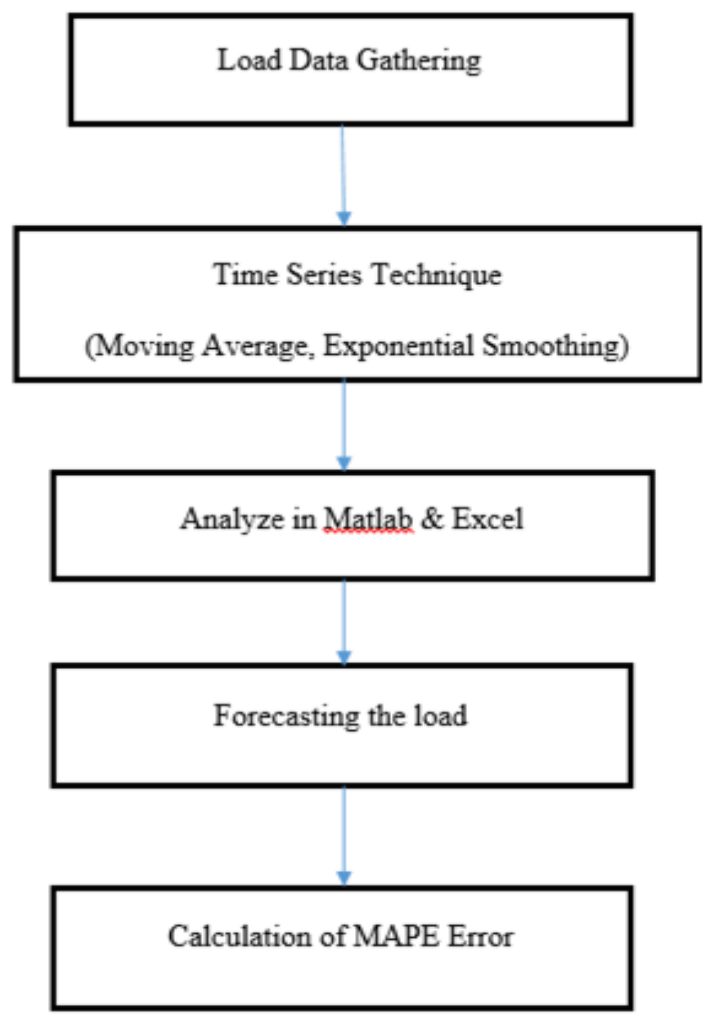

Figure 2: Load Forecasting Model for Moving Average \& Exponential Smoothing 
From these two method of short term load forecasting technique by artificial neural network \& time series method (moving averages \& exponential smoothing) the error can be calculated. The least efficient error method be the most appropriate method for the load forecasting. Therefore the ANN method be the best method of the load forecasting because these method having minimum error on the forecasting.

\subsection{Tool Selection}

For, all the predictions related to ANN Matlab 2018a is used and for time series methods statistical tool excel is used.

\subsection{Evaluation of Predicted Performance}

The forecasting performance of the trained network could be assessed by calculating the prediction error on samples other than those used during the training phase. Various error metrics between the actual and forecasted loads are presented and defined but the most commonly adopted by load forecasters are the Mean Absolute Percentage Errors (MAPE), the Absolute Percentage Errors (APE), the Mean Absolute Error (MAE) and the Mean Squared Error (MSE) or Root Mean Squared Error (RMSE).

$$
\begin{aligned}
& \text { MAPE }=\frac{1}{n} \sum_{i=1}^{n} \frac{\mid \text { actualLoad }(i)-\text { forecastedLoad }(i) \mid}{(\text { actualLoad })(i)} \times 100, \\
& A P E=\frac{\mid \text { actualLoad }- \text { forecastedLoad } \mid}{(\text { actualLoad })} \times 100, \\
& \text { MAE }=\frac{1}{n} \sum_{i=1}^{n} \frac{\mid \text { actualLoad }(i)-\text { forecastedLoad }(i) \mid}{(\text { actualLoad })(i)}, \\
& M S E=\frac{1}{n} \sum_{i=1}^{n}\left(t_{i}-0_{i}\right)^{2} \text { or } \sqrt{M S E},
\end{aligned}
$$

Where $n$ is the number of the data points and $i$ is the period at which the load is produced or forecasted, $t$ is the target and $O$ the NN output.

To make sure that the system is accurate, the relative error is retained on the hourly basis. In the case of positive error, it means the forecasted load is greater than the actual consumption load, and the opposite is true when the forecasted load was less than the actual load.

\subsection{Forecasting next hour using ANN}

Two input methods are tested for forecasting next hour load is set that the effects of power variables and additional input parameters. The forecast is done with historical load variables along with temperature variables, day type \& cyclic values of hour of day and day of week as input.

With properly synchronized additional variables the performance error MAPE, MSE etc. gets improved automatically.

Thus the formulated input vector and target variable is feed in the ANN to get predicted values using 2- layer feed forward network with sigmoid hidden neurons and linear output neurons. It can fit multi-dimensional mapping problems abnormally well given consistent data and enough neurons in its hidden layer. The neural network is trained with LevenbergMarquardt back propagation algorithm.
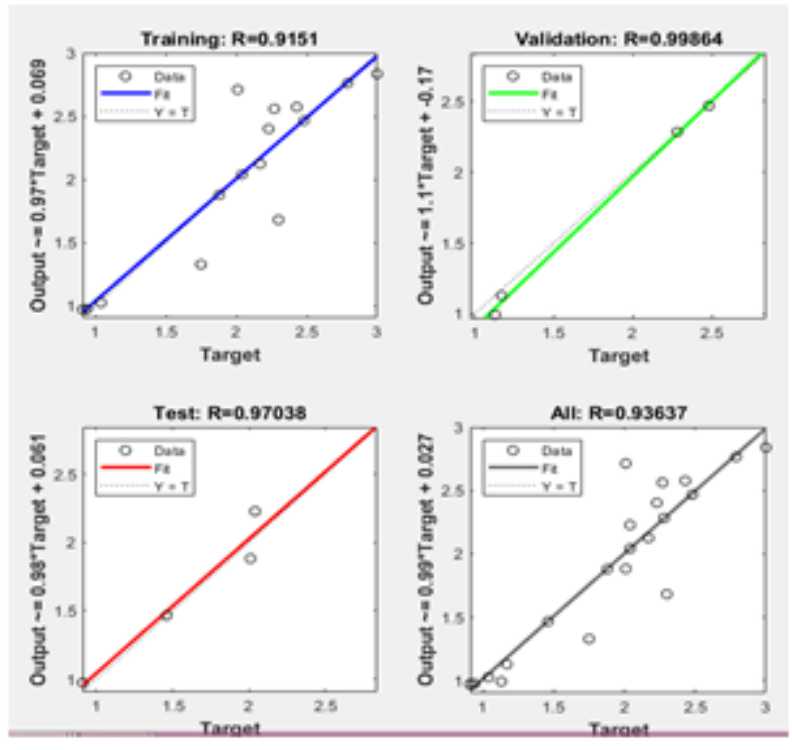

Fig 3: Neural Network Training Regression

Training of the Network: This is just a process of weight adjustments with respect to the targeted output by the neural network. The training of the network is carried out using the MATLAB software. The load data collected is the input data to the neural networks. $50 \%$ of this data was used for the training of the neural network, $25 \%$ was used for the validation and the remaining $25 \%$, for the forecast. The neural network was trained using different activation functions and number of layers till the best performance was obtained. Figure 5 shows the neural network being trained.

\subsection{Data Collection}

Combined hourly feeder data from $1^{\text {st }}$ Poush 2075 to $29^{\text {th }}$ Poush 2076 of the Bishnumati feeder of 132/11 Kv, collected from Balaju Substation, Nepal Electricity Authority. The raw data obtained had been recorded manually in Balaju Substation containing single excel sheet for daily load diagrams. The obtained data was then converted into single time series data. 
Similarly, hourly metrological data (temperature, humidity) was collected from department of Meteorology, Government of Nepal.

In this method of load forecasting using ANN method, we can be split the data into the inputs set, hidden layer sets, output layer and the output. For, this load forecasting using ANN methods we can be use temperature, previous hour load, humidity, in which days of load be forecast $\&$ whether the day be working day or not. The overall parameter of the neural network can be listed in table.

Table 1: Neural Network Architecture

\begin{tabular}{|l|l|l|l|}
\hline $\begin{array}{l}\text { Number } \\
\text { of } \\
\text { Inputs }\end{array}$ & $\begin{array}{l}\text { Number } \\
\text { of Hidden } \\
\text { layer } \\
\text { Neurons }\end{array}$ & $\begin{array}{l}\text { Number } \\
\text { of Output } \\
\text { Neuron }\end{array}$ & $\begin{array}{l}\text { Activation } \\
\text { Functions }\end{array}$ \\
\hline 5 & 10 & 1 & Sigmoid \\
\hline
\end{tabular}

\subsection{Time Series Architecture}

In this method of load forecasting we can be used two methods of time series analysis. These are moving average and the exponential smoothing technique. In this method of load forecasting the moving of three item can be analyzed and then be take into the fourth column. The exponential smoothing technique can also be used the same technique, at the starting we can be take the averages of hourly load and forecasted the load for next hour, next day and the next month.

\section{Objectives}

\subsection{Main Objective}

The main objective of this thesis is short term load forecasting using Artificial Neural Network and Time Series Method.

\subsection{Specific Objectives}

- To find the hourly basis data of temperature, humidity \& power.

- To identify the major network disturbances.

- To validate the data result with actual data.

\section{Results \& Discussion}

\subsection{Forecasted load with ANN Model}

The hourly load data of the Bishnumati Feeder 132/11 can be collected from the Balaju Substation. First of all we can set the input and the target model for the load forecasting. The input parameters are day, previous load, temperature, humidity \& the hour is working hour or not. The input \& targeted parameter of the 2076 mangsir $1^{\text {st }}$ are as follows:
Table 2: Input and Target Parameter for ANN Model

\begin{tabular}{|c|c|c|c|c|c|}
\hline $\begin{array}{c}\text { Ho } \\
\text { ur }\end{array}$ & $\begin{array}{c}\text { Previou } \\
\text { s } \\
\text { Load(M } \\
\text { W) }\end{array}$ & $\begin{array}{c}\text { Temperatur } \\
\text { e(Degree } \\
\text { centrigrate) }\end{array}$ & $\begin{array}{c}\text { Humid } \\
\text { ity(\%) }\end{array}$ & $\begin{array}{c}\text { worki } \\
\text { ng } \\
\text { hour/ } \\
\text { not }\end{array}$ & $\begin{array}{c}\text { Target( } \\
\text { MW) }\end{array}$ \\
\hline 1 & 0.97 & 4 & 88 & 0 & 0.97 \\
\hline 2 & 0.97 & 5 & 87 & 0 & 0.97 \\
\hline 3 & 0.97 & 6 & 88 & 0 & 0.97 \\
\hline 4 & 0.97 & 6 & 86 & 0 & 0.97 \\
\hline 5 & 0.94 & 6 & 89 & 0 & 1.13 \\
\hline 6 & 1.10 & 7 & 84 & 0 & 1.67 \\
\hline 7 & 1.68 & 8 & 88 & 1 & 2.30 \\
\hline 8 & 2.32 & 9 & 89 & 0 & 2.45 \\
\hline 9 & 2.46 & 9.5 & 85 & 0 & 2.25 \\
\hline 10 & 2.20 & 10 & 67 & 0 & 2.20 \\
\hline 11 & 2.19 & 12 & 70 & 0 & 2.17 \\
\hline 12 & 2.07 & 17 & 73 & 0 & 2.14 \\
\hline 13 & 2.09 & 18.5 & 75 & 0 & 2.14 \\
\hline 14 & 2.17 & 22 & 76 & 1 & 2.07 \\
\hline 15 & 2.06 & 19 & 77 & 0 & 2.14 \\
\hline 16 & 2.04 & 16 & 76 & 0 & 2.11 \\
\hline 17 & 2.02 & 14 & 74 & 0 & 2.54 \\
\hline 18 & 2.36 & 13 & 76 & 0 & 2.96 \\
\hline 19 & 2.91 & 12 & 74 & 0 & 2.79 \\
\hline 20 & 2.75 & 11 & 75 & 0 & 2.43 \\
\hline 21 & 2.38 & 6 & 74.5 & 0 & 2.11 \\
\hline 22 & 2.04 & 5 & 74.6 & 1 & 1.52 \\
\hline 23 & 1.49 & 4 & 74.2 & 0 & 1.20 \\
\hline 24 & 1.17 & 4 & 74.5 & 0 & 1.04 \\
\hline
\end{tabular}

The load Forecasting can be done on the on the following basics. The input and target value are given to the matlab toolbox and then analyzing the regression line. If the regression line is very close to unity, then there could be the accuracy of forecasted load.

Table 3: Calculation of Forecasted load \& APE

\begin{tabular}{|c|c|c|c|}
\hline $\begin{array}{c}\text { Ho } \\
\text { ur }\end{array}$ & $\begin{array}{c}\text { Actual load, } \\
\text { MW }\end{array}$ & $\begin{array}{c}\text { Forecasted } \\
\text { load, MW }\end{array}$ & $\begin{array}{c}\text { Absolute } \\
\text { Percentage Error }\end{array}$ \\
\hline 1 & 0.94 & 0.974823 & 0.037859 \\
\hline 2 & 0.94 & 0.975202 & 0.038262 \\
\hline 3 & 0.91 & 0.974341 & 0.074394 \\
\hline 4 & 0.91 & 0.971354 & 0.0711 \\
\hline 5 & 1.13 & 0.993563 & 0.123528 \\
\hline 6 & 1.75 & 1.32966 & 0.239749 \\
\hline 7 & 2.30 & 1.68225 & 0.268452 \\
\hline
\end{tabular}




\begin{tabular}{|c|c|c|c|}
\hline 8 & 2.48 & 2.468294 & 0.003801 \\
\hline 9 & 2.28 & 2.283354 & $1.23 \mathrm{E}-05$ \\
\hline 10 & 2.27 & 2.563162 & 0.130547 \\
\hline 11 & 2.23 & 2.403972 & 0.075699 \\
\hline 12 & 2.17 & 2.126062 & 0.020258 \\
\hline 13 & 2.04 & 2.042409 & 0.000951 \\
\hline 14 & 2.01 & 2.714401 & 0.351739 \\
\hline 15 & 1.88 & 1.880662 & 0.001137 \\
\hline 16 & 2.01 & 1.883253 & 0.062163 \\
\hline 17 & 2.43 & 2.577683 & 0.061155 \\
\hline 18 & 3.00 & 2.839645 & 0.052165 \\
\hline 19 & 2.79 & 2.766072 & 0.00694 \\
\hline 20 & 2.48 & 2.469414 & 0.003349 \\
\hline 21 & 2.04 & 2.22909 & 0.09244 \\
\hline 22 & 1.46 & 1.466409 & 0.006128 \\
\hline 23 & 1.17 & 1.129685 & 0.031131 \\
\hline 24 & 1.04 & 1.02559 & 0.010458 \\
\hline
\end{tabular}

$\% \mathrm{MAPE}=6.34 \%$

The graph that can be compares the Actual Load and Forecasted load of the Mangsir $1^{\text {st }}$ load, the maximum load in 9 hour and minimum in $1^{\text {st }}$ hour.This gives actual forecast:

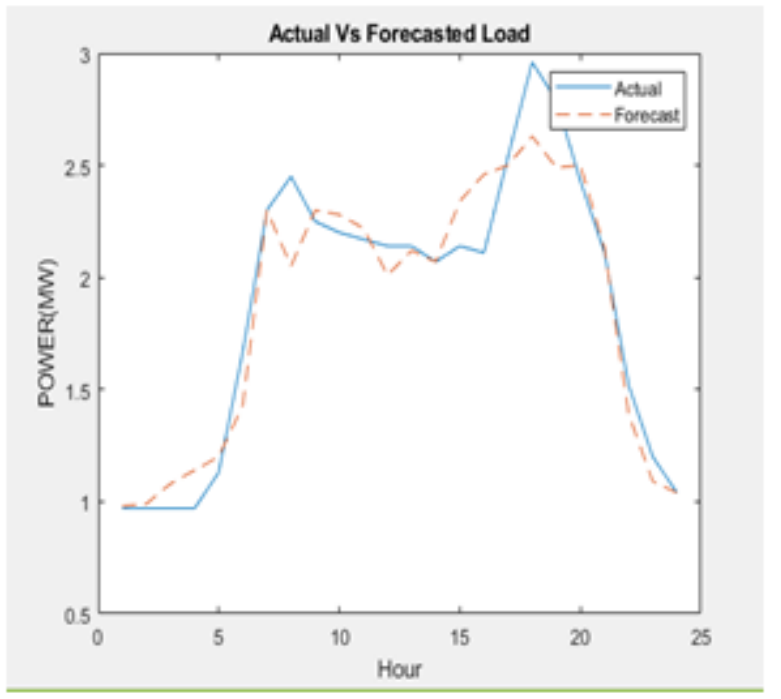

Figure 4: Actual Vs Forecasted Load of mangsir $1^{\text {st }}$

\subsection{Forecasted load on the basis of Moving Average}

Load can be forecasted on the basis of moving average and the exponential smoothing. This type of method uses the load at input and the output can be analyzed on the basis of 3 point, 4 point, 5 point moving averages. Exponential smoothing technique is very efficient and beneficial method.

The mangsir $1^{\text {st }}$ load can be analyzed on the basis of Moving point averages:

Table 4: Load forecasting using Moving Averages of mangsir $1^{\text {st }}$

\begin{tabular}{|c|c|c|c|c|}
\hline & & 3Point MA & $\begin{array}{l}4 \text { Point } \\
\text { MA }\end{array}$ & $\begin{array}{l}5 \text { Point } \\
\text { MA }\end{array}$ \\
\hline $\begin{array}{l}\text { Time(h } \\
\text { rs.) }\end{array}$ & $\begin{array}{l}\text { Actual(M } \\
\text { W) }\end{array}$ & $\begin{array}{l}\text { Forecast( } \\
\mathrm{MW})\end{array}$ & $\begin{array}{l}\text { Forecast( } \\
\mathrm{MW})\end{array}$ & $\begin{array}{l}\text { Forecast( } \\
\text { MW) }\end{array}$ \\
\hline 1 & 0.97 & 1.57 & 2.17 & 2.49 \\
\hline 2 & 0.97 & 1.21 & 1.77 & 2.32 \\
\hline 3 & 0.97 & 1.04 & 1.42 & 1.97 \\
\hline 4 & 0.97 & 0.97 & 1.15 & 1.61 \\
\hline 5 & 1.13 & 0.97 & 0.97 & 1.33 \\
\hline 6 & 1.67 & 1.03 & 1.01 & 1.00 \\
\hline 7 & 2.30 & 1.26 & 1.19 & 1.14 \\
\hline 8 & 2.45 & 1.70 & 1.52 & 1.41 \\
\hline 9 & 2.25 & 2.14 & 1.89 & 1.70 \\
\hline 10 & 2.20 & 2.33 & 2.17 & 1.96 \\
\hline 11 & 2.17 & 2.30 & 2.30 & 2.17 \\
\hline 12 & 2.14 & 2.21 & 2.27 & 2.27 \\
\hline 13 & 2.14 & 2.17 & 2.19 & 2.24 \\
\hline 14 & 2.07 & 2.15 & 2.16 & 2.18 \\
\hline 15 & 2.14 & 2.12 & 2.13 & 2.14 \\
\hline 16 & 2.11 & 2.12 & 2.12 & 2.13 \\
\hline 17 & 2.54 & 2.11 & 2.11 & 2.12 \\
\hline 18 & 2.96 & 2.26 & 2.21 & 2.20 \\
\hline 19 & 2.79 & 2.54 & 2.44 & 2.36 \\
\hline 20 & 2.43 & 2.76 & 2.60 & 2.51 \\
\hline 21 & 2.11 & 2.73 & 2.68 & 2.57 \\
\hline 22 & 1.52 & 2.44 & 2.57 & 2.57 \\
\hline 23 & 1.20 & 2.02 & 2.21 & 2.36 \\
\hline 24 & 1.04 & 1.61 & 1.81 & 2.01 \\
\hline $\begin{array}{c}\% \text { MAP } \\
\text { E }\end{array}$ & & $12 \%$ & $11.23 \%$ & $11.44 \%$ \\
\hline
\end{tabular}

The MAPE of these forecasted load be slightly higher than the ANN method again then other 5 days of one week MAPE are listed in table below.

Table 5: Forecasted Value for different day of Mangsir

\begin{tabular}{|c|c|c|c|}
\hline & \multicolumn{3}{|c|}{ Moving Average MAPE\% } \\
\hline Date & 3 Point & 4 Point & 5 Point \\
\hline Mangsir 2 $^{\text {nd }}$ & $10.34 \%$ & $10.55 \%$ & $11 \%$ \\
\hline Mangsir 3 $^{\text {rd }}$ & $9 \%$ & $9.04 \%$ & $10.35 \%$ \\
\hline Mangsir 4 $^{\text {th }}$ & $10 \%$ & $9.55 \%$ & $11 \%$ \\
\hline Mangsir 5 $^{\text {th }}$ & $11 \%$ & $10.45 \%$ & $12 \%$ \\
\hline Mangsir 6 $^{\text {th }}$ & $10.5 \%$ & $10.50 \%$ & $11 \%$ \\
\hline
\end{tabular}




\begin{tabular}{|l|l|l|l|}
\hline Mangsir $7^{\text {th }}$ & $9.5 \%$ & $11 \%$ & $10.42 \%$ \\
\hline
\end{tabular}

\subsection{Forecasted load on the basis of Exponential Smoothing}

Exponential Smoothing is the best technique for electrical load forecasting. The forecasting of load for seven days of Mangsir be listed as follows. The forecasted load can be calculated on the basis of different value of alpha. The forecasted load for the seven days can be calculated as follows \& all the forecasted load are in Mega Watt.

Table 6: Forecasted load on the basis of Exponential Smoothing

\begin{tabular}{|c|c|c|c|c|}
\hline & & $a=0.1$ & $a=0.2$ & $a=0.3$ \\
\hline Time(Hr.) & $\begin{array}{c}\text { Actual } \\
\text { load }\end{array}$ & $\begin{array}{c}\text { Forecast } \\
\text { load }\end{array}$ & $\begin{array}{c}\text { Forecast } \\
\text { load }\end{array}$ & $\begin{array}{c}\text { Forecast } \\
\text { load }\end{array}$ \\
\hline 1 & 0.972 & 0.972 & 0.972 & 0.972 \\
\hline 2 & 0.972 & 0.972 & 0.972 & 0.972 \\
\hline 3 & 0.972 & 0.972 & 0.972 & 0.972 \\
\hline 4 & 0.972 & 0.972 & 0.972 & 0.972 \\
\hline 5 & 1.134 & 0.972 & 0.972 & 0.972 \\
\hline 6 & 1.668 & 0.988 & 1.004 & 1.520 \\
\hline 7 & 2.300 & 1.056 & 1.140 & 2.215 \\
\hline 8 & 2.445 & 1.180 & 1.389 & 2.540 \\
\hline 9 & 2.251 & 1.307 & 1.642 & 1.812 \\
\hline 10 & 2.202 & 1.401 & 1.831 & 1.943 \\
\hline 11 & 2.170 & 1.481 & 1.991 & 2.021 \\
\hline 12 & 2.138 & 1.550 & 2.129 & 2.066 \\
\hline 13 & 2.138 & 1.609 & 2.246 & 2.087 \\
\hline 14 & 2.073 & 1.662 & 2.352 & 2.102 \\
\hline 15 & 2.138 & 1.703 & 2.434 & 2.094 \\
\hline 16 & 2.105 & 1.746 & 2.521 & 2.107 \\
\hline 17 & 2.542 & 1.782 & 2.593 & 2.106 \\
\hline 18 & 2.964 & 1.858 & 2.745 & 2.237 \\
\hline 19 & 2.785 & 1.969 & 2.966 & 2.455 \\
\hline 20 & 2.429 & 2.051 & 3.129 & 2.554 \\
\hline 21 & 2.105 & 2.088 & 3.205 & 2.517 \\
\hline 22 & 1.522 & 2.090 & 3.208 & 2.393 \\
\hline 23 & 1.198 & 1.233 & 3.095 & 1.432 \\
\hline 24 & 1.036 & 1.250 & 1.928 & 1.852 \\
\hline \%MAPE & & $8 \%$ & $9 \%$ & $8.46 \%$ \\
\hline
\end{tabular}

The graph that can be plotted below in figure:

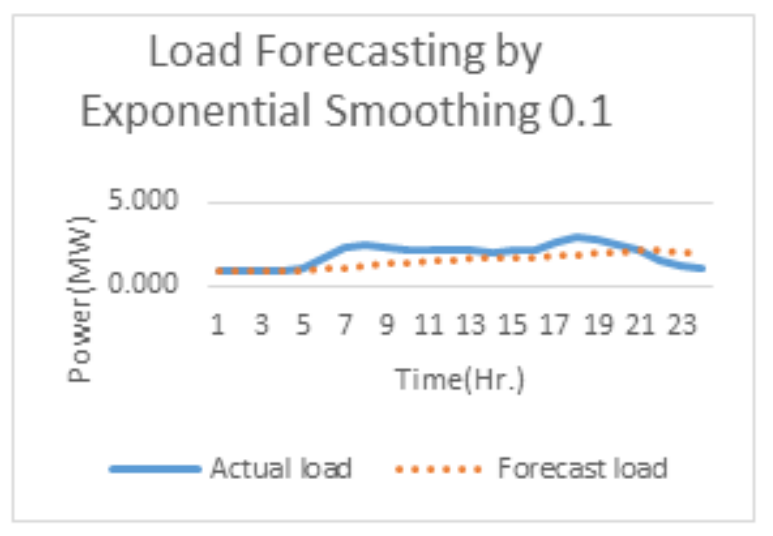

Figure 5: Comparison between Actual load and Forecasted load at alpha 0.1 .

When the value of alpha be 0.3 , the graph that can be plotted as:

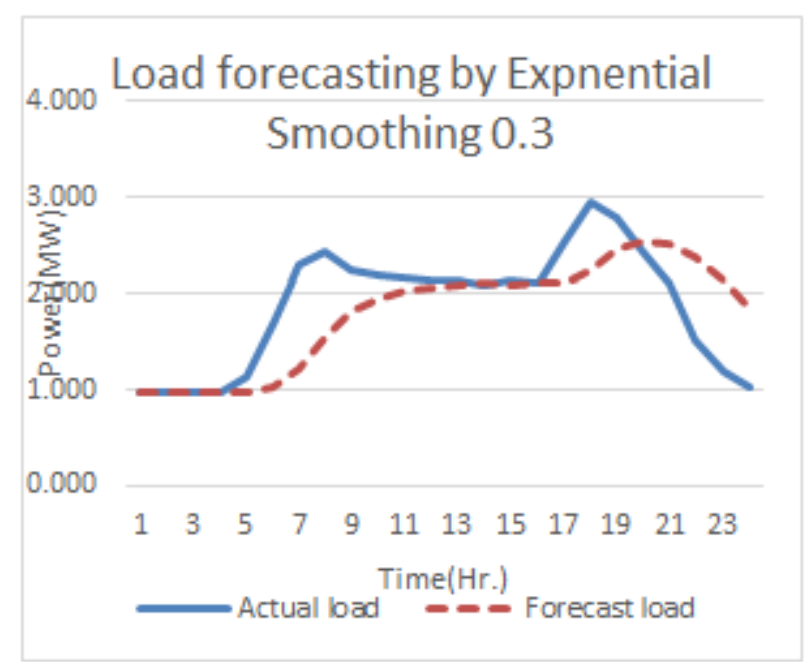

Figure 6: Forecasting using exponential smoothing using alpha 0.3

Others day of the mangsir are listed are as follows:

Table 7: Forecasted load by exponential smoothing

\begin{tabular}{|c|c|c|c|}
\hline & \multicolumn{3}{|c|}{ Forecasted MAPE\% } \\
\hline & 0.1 & 0.2 & 0.3 \\
\hline Mangsir 1 $^{\text {st }}$ & $8 \%$ & $9 \%$ & $8.46 \%$ \\
\hline mangsir 2 $^{\text {nd }}$ & $7.46 \%$ & $7.99 \%$ & $8.20 \%$ \\
\hline mangsir 3 & $6.22 \%$ & $7 \%$ & $7.79 \%$ \\
\hline mangsir 4 & $6.89 \%$ & $8 \%$ & $8 \%$ \\
\hline mangsir 5 & $6.42 \%$ & $7 \%$ & $8.22 \%$ \\
\hline mangsir 6 & $7.02 \%$ & $7.40 \%$ & $8.11 \%$ \\
\hline mangsir 7 & $7.49 \%$ & $8.42 \%$ & $8.5 \%$ \\
\hline
\end{tabular}


This can be indicates that MAPE is maximum on the mangsir $1^{\text {st }}$ load and indicates minimum in the Tuesday of the normal week. Therefore the mape is maximum on Sunday, because of Sunday be the starting period of the week, but the Tuesday be normal days of week. Therefore mape is maximum in starting and minimum in Tuesday of a week. Other day are fluctuating in-between these maximum and minimum ranges.

\begin{tabular}{|c|c|c|c|c|}
\hline $\begin{array}{c}\mathrm{Da} \\
\mathrm{y}\end{array}$ & ANN & $\begin{array}{l}\text { Moving } \\
\text { Average }\end{array}$ & $\begin{array}{l}\text { Exponential } \\
\text { Smoothing }\end{array}$ & $\begin{array}{c}\text { Actual } \\
\text { Load }\end{array}$ \\
\hline 1 & $\begin{array}{c}0.97482 \\
3\end{array}$ & 1.57 & 0.972 & 0.97 \\
\hline 2 & $\begin{array}{c}0.97520 \\
2\end{array}$ & 1.21 & 0.971965 & 0.97 \\
\hline 3 & $\begin{array}{c}0.97434 \\
1\end{array}$ & 1.04 & 0.971934 & 0.97 \\
\hline 4 & $\begin{array}{c}0.97135 \\
4\end{array}$ & 0.97 & 0.971906 & 0.97 \\
\hline 5 & $\begin{array}{c}0.99356 \\
3\end{array}$ & 0.97 & 0.97188 & 1.13 \\
\hline 6 & 1.32966 & 1.03 & 0.988052 & 1.67 \\
\hline 7 & 1.68225 & 1.26 & 1.056047 & 2.30 \\
\hline 8 & $\begin{array}{c}2.46829 \\
4\end{array}$ & 1.70 & 1.1804 & 2.45 \\
\hline 9 & $\begin{array}{c}2.28335 \\
4\end{array}$ & 2.14 & 1.306892 & 2.25 \\
\hline 10 & $\begin{array}{c}2.56316 \\
2\end{array}$ & 2.33 & 1.401302 & 2.20 \\
\hline 11 & $\begin{array}{c}2.40397 \\
2\end{array}$ & 2.30 & 1.481413 & 2.17 \\
\hline 12 & $\begin{array}{c}2.12606 \\
2\end{array}$ & 2.21 & 1.550274 & 2.14 \\
\hline 13 & $\begin{array}{c}2.04240 \\
9\end{array}$ & 2.17 & 1.60901 & 2.14 \\
\hline 14 & $\begin{array}{c}2.71440 \\
1\end{array}$ & 2.15 & 1.661873 & 2.07 \\
\hline 15 & $\begin{array}{c}1.88066 \\
2\end{array}$ & 2.12 & 1.702971 & 2.14 \\
\hline 16 & $\begin{array}{c}1.88325 \\
3\end{array}$ & 2.12 & 1.746437 & 2.11 \\
\hline 17 & $\begin{array}{c}2.57768 \\
3\end{array}$ & 2.11 & 1.782318 & 2.54 \\
\hline 18 & $\begin{array}{c}2.83964 \\
5\end{array}$ & 2.26 & 1.858335 & 2.96 \\
\hline 19 & $\begin{array}{c}2.76607 \\
2\end{array}$ & 2.54 & 1.968856 & 2.79 \\
\hline 20 & $\begin{array}{c}2.46941 \\
4\end{array}$ & 2.76 & 2.05051 & 2.43 \\
\hline 21 & 2.22909 & 2.73 & 2.088372 & 2.11 \\
\hline 22 & $\begin{array}{c}1.46640 \\
9\end{array}$ & 2.44 & 2.09006 & 1.52 \\
\hline
\end{tabular}

\begin{tabular}{|c|c|c|c|c|}
\hline 23 & $\begin{array}{c}1.12968 \\
5\end{array}$ & 2.02 & 2.033279 & 1.20 \\
\hline 24 & 1.02559 & 1.61 & 1.949788 & 1.04 \\
\hline
\end{tabular}

\subsection{Comparison of MAPE for different days.}

The electric load can be forecasted on the basis of next hour forecast and the next day forecast. The MAPE error of the next hour error is less than the next day error, because in next day error there should neglected different parameters of input.

\begin{tabular}{|c|c|c|c|c|c|c|}
\hline \multicolumn{7}{|c|}{ MAPE for different days } \\
\hline & \multicolumn{3}{|c|}{ Next hour } & \multicolumn{3}{|c|}{ Next Day } \\
\hline Day & $\begin{array}{l}\mathrm{A} \\
\mathrm{N} \\
\mathrm{N}\end{array}$ & $\begin{array}{l}\text { M } \\
\text { ovi } \\
\text { ng } \\
\text { Av } \\
\text { era } \\
\text { ge }\end{array}$ & $\begin{array}{l}\text { Expon } \\
\text { ential } \\
\text { smoot } \\
\text { hing }\end{array}$ & $\begin{array}{l}\text { AN } \\
\mathrm{N}\end{array}$ & $\begin{array}{l}\text { Mov } \\
\text { ing } \\
\text { Aver } \\
\text { agee }\end{array}$ & $\begin{array}{l}\text { Exponential } \\
\text { smoothing }\end{array}$ \\
\hline Sun & $\begin{array}{l}6 . \\
34 \\
\% \\
\end{array}$ & $\begin{array}{l}12 \\
\%\end{array}$ & $8 \%$ & $\begin{array}{l}7 . \\
34 \\
\% \\
\end{array}$ & $\begin{array}{l}12.2 \\
4 \%\end{array}$ & $9 \%$ \\
\hline $\begin{array}{l}\text { Mo } \\
n\end{array}$ & $\begin{array}{l}4 . \\
76 \\
\%\end{array}$ & $\begin{array}{l}10 \\
.3 \\
4 \\
\%\end{array}$ & $\begin{array}{c}7.46 \\
\%\end{array}$ & $\begin{array}{l}6 . \\
67 \\
\%\end{array}$ & $\begin{array}{l}11.3 \\
2 \%\end{array}$ & $7.55 \%$ \\
\hline Tue & $\begin{array}{l}3 . \\
67 \\
\%\end{array}$ & $\begin{array}{l}9 \\
\%\end{array}$ & $\begin{array}{c}6.22 \\
\%\end{array}$ & $\begin{array}{l}5 . \\
43 \\
\%\end{array}$ & $\begin{array}{c}9.40 \\
\%\end{array}$ & $7 \%$ \\
\hline $\begin{array}{l}\text { We } \\
\text { d }\end{array}$ & $\begin{array}{l}3 . \\
78 \\
\%\end{array}$ & $\begin{array}{l}10 \\
\%\end{array}$ & $\begin{array}{c}6.89 \\
\%\end{array}$ & $\begin{array}{l}6 . \\
34 \\
\%\end{array}$ & $\begin{array}{c}10.7 \\
2 \%\end{array}$ & $7.22 \%$ \\
\hline Thu & $\begin{array}{l}4 . \\
66 \\
\% \\
\end{array}$ & $\begin{array}{l}11 \\
\%\end{array}$ & $\begin{array}{c}6.42 \\
\%\end{array}$ & $\begin{array}{c}6 . \\
46 \\
\% \\
\end{array}$ & $\begin{array}{c}11.2 \\
2 \%\end{array}$ & $6.66 \%$ \\
\hline Fri & $\begin{array}{l}5 . \\
84 \\
\%\end{array}$ & $\begin{array}{l}10 \\
.5 \\
0 \\
\%\end{array}$ & $\begin{array}{c}7.02 \\
\%\end{array}$ & $\begin{array}{l}7 \\
\%\end{array}$ & $\begin{array}{l}10 \\
\%\end{array}$ & $7.42 \%$ \\
\hline Sat & $\begin{array}{l}5 . \\
56 \\
\% \\
\end{array}$ & $\begin{array}{l}9 . \\
50 \\
\%\end{array}$ & $\begin{array}{c}7.49 \\
\%\end{array}$ & $\begin{array}{l}6 . \\
86 \\
\%\end{array}$ & $9 \%$ & $8 \%$ \\
\hline
\end{tabular}

From these three methods of load forecasting using next day forecasting using hourly basis. The ann method have a minimum error as compared with the moving average and the exponential smoothing method. The maximum error occurred in Sunday because of peak day and minimum error in Tuesday. The comparison graph as shown in below: 


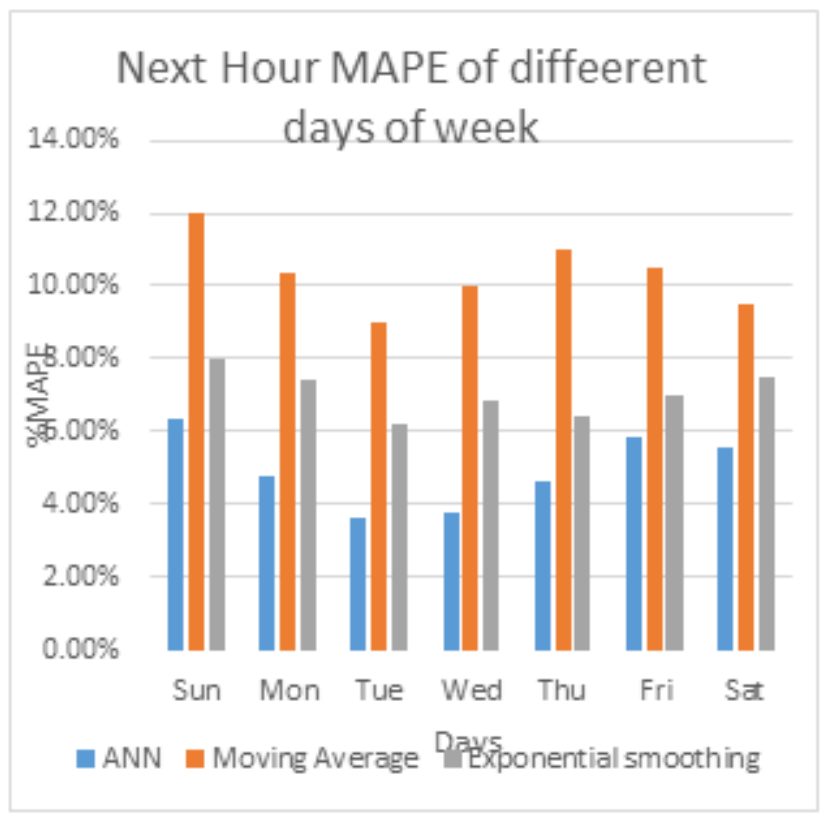

Figure 7: Next hour MAPE of different days of week

Again, the load forecasting can be done rather than the average of hour and can be used directly previous days load

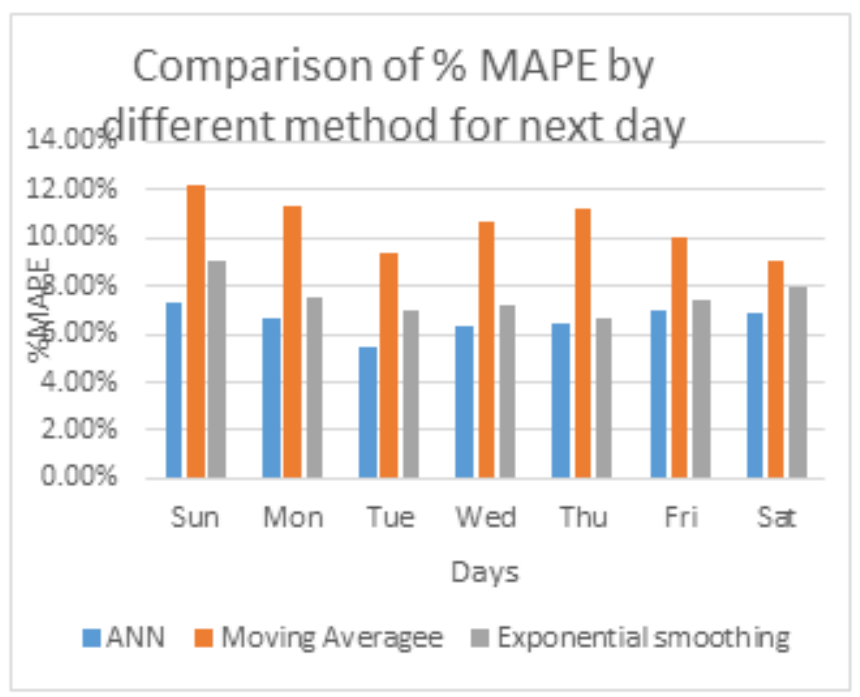

Figure .8: Comparison of MAPE for next day

\subsection{Calculation of MAPE for different Month}

The calculation of MAPE for different month can be calculated on the basis of input and the target parameters. The input parameter be previous days load, temperature, humidity, whether the working day be worked or holiday, and the number of days that can be used. The forecasted load can be calculated on the basis of regression line. The MAPE for the different month can be listed as follows.
Table 4.12: \%MAPE for different month

\begin{tabular}{|l|c|c|c|}
\hline Month & ANN & Moving Average & $\begin{array}{c}\text { Exponential } \\
\text { Smoothing }\end{array}$ \\
\hline $\begin{array}{l}\text { Poush- } \\
1\end{array}$ & $4.76 \%$ & $7 \%$ & $5 \%$ \\
\hline $\begin{array}{l}\text { Magh- } \\
1\end{array}$ & $6.74 \%$ & $9 \%$ & $8 \%$ \\
\hline $\begin{array}{l}\text { falgun- } \\
1\end{array}$ & $5.76 \%$ & $9.20 \%$ & $6 \%$ \\
\hline $\begin{array}{l}\text { chaitra } \\
-1\end{array}$ & $6.76 \%$ & $10 \%$ & $10 \%$ \\
\hline $\begin{array}{l}\text { Baisakh } \\
-1\end{array}$ & $7.44 \%$ & $9 \%$ & $8 \%$ \\
\hline $\begin{array}{l}\text { Jestha- } \\
1\end{array}$ & $8.95 \%$ & $12 \%$ & $11 \%$ \\
\hline $\begin{array}{l}\text { Asadh- } \\
1\end{array}$ & $6 \%$ & $12 \%$ & $12 \%$ \\
\hline $\begin{array}{l}\text { Shawa } \\
\text { n-1 }\end{array}$ & $6 \%$ & $10 \%$ & $8 \%$ \\
\hline $\begin{array}{l}\text { Bhadra } \\
-1\end{array}$ & $6.50 \%$ & $10.92 \%$ & $7 \%$ \\
\hline $\begin{array}{l}\text { Ashwin } \\
-1\end{array}$ & $6.67 \%$ & $10.62 \%$ & $6 \%$ \\
\hline $\begin{array}{l}\text { Kartik- } \\
1\end{array}$ & $6 \%$ & $8 \%$ & $82 \%$ \\
\hline $\begin{array}{l}\text { Mangsi } \\
\text {-1 }\end{array}$ & $5.52 \%$ & $8.72 \%$ & \\
\hline
\end{tabular}

From these table, we can be conclude that the maximum MAPE occurs in jestha month and the minimum MAPE on poush. Because of monsoon change in jestha ashar month and load will be fluctuated, then there will be maximum error occur. The histogram plot of MAPE of different method are shown bwlow

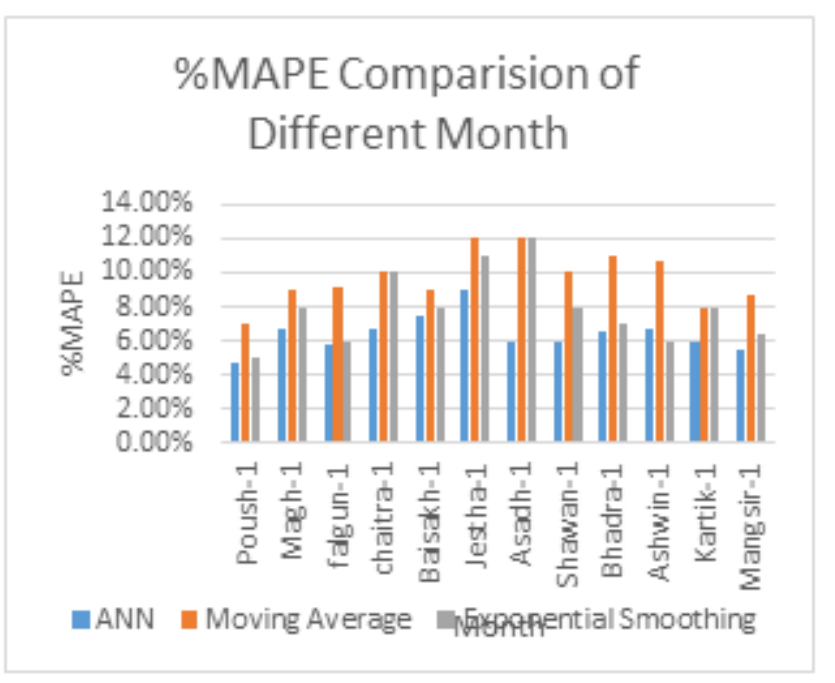

Figure 9: \%MAPE comparison of different month 
These shows the maximum and minimum value of MAPE for different month can be listed in above figure.

\section{Conclusion}

Artificial Neural Network model was developed incorporating the statistical method. In this research we can be compared the statistical method and the artificial method, the mean absolute percentage error of the ANN be less than as compare with the moving average and the exponential smoothing technique.

An artificial neural network method can be used different parameters as an input while the statistical method can only use one input. Therefore the accuracy of the ANN method of load forecasting can be more accuracy than the other methods.

The MAPE of the mangsir $1^{\text {st }}$ be $6.34 \%$ and $12 \%$ for ANN method and the moving averages method. From these we can be concluding that load forecasting can be done on the basis of neural network.

\section{ACKNOWLEDGEMENT}

The authors extend their hearty gratitude to the faculties and colleagues at Tribhuvan University, Institute of Engineering, Pulchowk Campus and engineers of Nepal Electricity Authority for their constant help, support and recommendations.

\section{REFERENCES}

[1] C. C. Hsu and C. Y. Chen, "Regional load forecasting in Taiwan Applications of artificial neural networks," Energy Convers. Manag., vol. 44, no. 12, pp. 1941-1949, 2003, doi: 10.1016/S01968904(02)00225-X.

M. D., A. A. Ayeni, and M. A., "Short Term Electric Load Forecasting using Neural Network and Genetic Algorithm," Int. J. Appl. Inf. Syst., vol. 10, no. 4, pp. 22-28, 2016, doi: 10.5120/ijais2016451490.

[3] S. S. Reddy and J. A. Momoh, "Short term electrical load forecasting using back propagation neural networks," 2014 North Am. Power Symp. NAPS 2014, pp. 1-6, 2014, doi: 10.1109/NAPS.2014.6965453.

S. Saravanan, S. Kannan, and C. Thangaraj, "INDIA , S ELECTRICITY DEMAND FORECAST USING REGRESSION ANALYSIS AND ARTIFICIAL NEURAL NETWORKS BASED ON PRINCIPAL COMPONENTS," vol. 6956, no. July 2012, pp. 365-370, 2020, doi: 10.21917/ijsc.2012.0057.

A. K. Jain, J. Mao, and K. M. Mohiuddin, "Artificial neural networks: A tutorial," Computer, vol. 29, no. 3. pp. 31-44, 1996, doi: 10.1109/2.485891.

M. Buhari and S. S. Adamu, "Short-Term Load Forecasting Using Artificial Neural Network," no. March, pp. 1-7, 2012, doi: 10.13140/2.1.3687.0085.

M. K. Singla, J. Gupta, and P. Nijhawan, "Comparative study on backpropagation and levenberg marquardt algorithm on short term load forecasting," Int. J. Adv. Trends Comput. Sci. Eng., vol. 8, no.
2, pp. 194-202, 2019, doi: 10.30534/ijatcse/2019/14822019.

[8] J. Sruthi and R. L. H. Catherine, "A Review on Electrical Load Forecasting in Energy Management 1 1," vol. 2, no. 3, pp. 670-676, 2015.

[9] Y. Yang, Y. Meng, Y. Xia, Y. Lu, and H. Yu, "An Efficient Approach for Short Term Load Forecasting," vol. I, 2011.

Suman Adhikari: Dept. of Mechanical Engineering Institute of Engineerng, Pulchowk Campus, TU, Pulchowk, Lalitpur

Prof. Dr. Laxman Poudel: Dept. of Mechanical Engineering Institute of Engineering, Pulchowk Campus, TU, Pulchowk, Lalitpur 